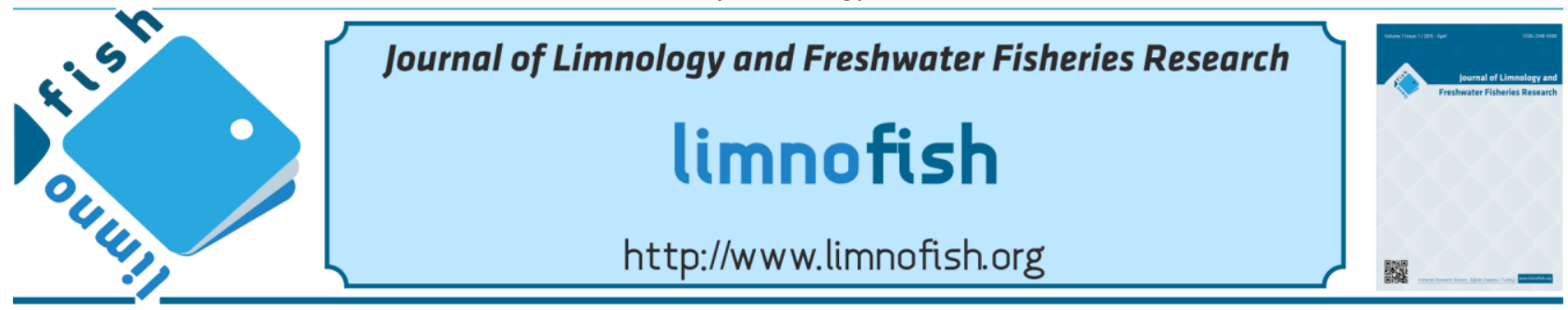

\title{
Age, Growth and Reproductive Period of White Bream, Blicca bjoerkna (L., 1758) in Lake Ladik, Turkey
}

\author{
Savaş YILMAZ ${ }^{1, *}$, Okan YAZICIOĞLU², Ramazan YAZICI ${ }^{3}$, Nazmi POLAT $^{1}$ \\ ${ }^{1}$ Ondokuz Mayis University, Faculty of Arts and Science, Department of Biology, Samsun-Turkey \\ ${ }^{2}$ Ahi Evran University, Technical Vocational Schools of Higher Education, Botanic and Animal Production Department, Organic \\ Farming Program, Kırşehir-Turkey \\ ${ }^{3}$ Ahi Evran University, Çiçekdağı Technical Vocational Schools of Higher Education, Laboratory and Veterinary Health \\ Department, Kırşehir-Turkey
}

\section{A B STRACT}

The white bream, Blicca bjoerkna (L., 1758) specimens $(n=434)$ were collected from Lake Ladik between November 2009 and October 2010 in order to determine the age, growth, and reproductive season. Fork lengths and weights of these samples varied between $11.5-24.3 \mathrm{~cm}$ and $22.80-259.00 \mathrm{~g}$, respectively. Age estimates obtained from scales and vertebrae were compared to determine the most reliable bony structure for ageing. The precision analyses indicated that scales were the most appropriate hard structures for determining the age of white bream. Ages of all the specimens ranged from I to VI years and age group III was dominant. The parameters of the von Bertalanffy growth equations were calculated as $L_{\infty}=32.85 \mathrm{~cm}, W_{\infty}=707.76 \mathrm{~g}, k=0.11$ year $^{-1}$ and $t_{0}=-2.64$ year, and the growth performance index $\left(\Phi^{\prime}\right)$ value was computed as 2.074 for combined sexes. Fork length-weight relationship was found to be $W=0.0066 F L^{3.317}$. The mean condition factor was the highest in August and the lowest in October. The gonadosomatic index values showed that the reproduction occurred between May and June.

Keywords: Ageing, scale, growth, reproduction season, Blicca bjoerkna, Lake Ladik

\section{ARTICLE INFO}

\section{RESEARCH ARTICLE}

Received : 08.01.2015

Revised : : 16.03.2015

Accepted : :17.03.2015

Published : 20.04.2015

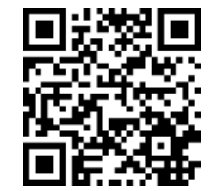

\section{* CORRESPONDING AUTHOR}

savas.yilmaz@omu.edu.tr

Tel : +903623121919

Fax: +90 3624576081

\section{Ladik Gölü (Türkiye)'ndeki Tahta Balığı, Blicca bjoerkna (L., 1758)'nın Yaşı, Büyümesi ve Üreme Dönemi}

Öz: Tahta Balığı, Blicca bjoerkna (L., 1758) örnekleri $(n=434)$ yaş, büyüme ve üreme dönemini belirlemek amaciyla Kasım 2009-Ekim 2010 tarihleri arasında Ladik Gölü’nden yakalanmıştır. Çatal boy ve ağırlık dağılımları sırasıyla 11,5-24,3 cm ve 22,80-259,00 g arasında değişmiştir. Pul ve omurdan elde edilen yaşlar en güvenilir kemiksi yapının tespit edilmesi amacıyla karşılaştırılmıştır. Uyum analizleri Tahta Balığı'nın yaşının belirlenmesi için en uygun yapının pul olduğunu göstermiştir. Örneklerin yaşları I-VI arasında dağılım göstermiş ve III yaş grubu baskın yıl sınıfını oluşturmuştur. Populasyon genelinde von Bertalanffy büyüme denklemi parametreleri $L_{\infty}=32,85 \mathrm{~cm}, W_{\infty}=707,76 \mathrm{~g}, k=0,11 \mathrm{yll}^{-1}$ ve $t_{0}=-2,64$ y1l ve büyüme performans indeks değeri $\left(\Phi^{\prime}\right)$ 2,074 olarak hesaplanmıştır. Çatal boy-ağırlık ilișkisi $W=0,0066 C ̧ B^{3,317}$ şeklinde elde edilmiştir. En yüksek ve en düşük ortalama kondisyon faktörü değerleri sırasıyla Ağustos ve Ekim aylarında elde edilmiştir. Gonadosomatik indeks değerleri üreme faaliyetinin Mayıs-Haziran aylarında gerçekleştiğini göstermiştir.

Anahtar kelimeler: Yaş tayini, pul, büyüme, üreme dönemi, Blicca bjoerkna, Ladik Gölü

\section{Introduction}

Age and growth information is very important for fisheries science (DeVries and Frie 1996). Studies on the age and growth of fishes are crucial for the understanding of vital features such as lifespan, age at recruitment, age at sexual maturity, reproduction periods, migrations, mortality of species and populations (Pontual et al. 2002). Therefore, the age of fish must be determined accurately (Polat 2000). One of the main problems in age and growth estimates is the selection of the most reliable bony structure for the ageing procedure (Abecasis et al. 2008). The most suitable method of age determination may vary among different fish species or different populations of the same species (Khan et al. 2011). Thus, evaluation of precision of different calcified structures by multiple readers should be performed (Stolarski and Sutton 2013).

The white bream, Blicca bjoerkna (L., 1758) is widespread in Europe and Asia continents 
(Kottelat and Freyhof 2007). This species is distributed in a large area from eastern side of England up to the Caspian Sea basin. It has entered to Turkey from northern Europe and it is found in Apolyont (Uluabat), Manyas (Kuş), Sapanca and Ladik lakes, Kura River, Sakarya River basin and the inland waters of Thrace region (Geldiay and Balık 2007). White breams generally prefer calm waters and they live in great lakes and lower parts of rivers (Kottelat and Freyhof 2007). $B$. bjoerkna is a freshwater fish; however, it also inhabits in brackish waters (Geldiay and Balık 2007). The euryphagous white bream feeds on mainly benthic invertebrates (Wielgosz and Tadajewska 1988). They spawn in May-July at temperatures above $15{ }^{\circ} \mathrm{C}$ (Kottelat and Freyhof 2007). This species does not have any commercial value because of its unpleasant taste. However, it is an important prey for top predators such as Esox lucius (Wysujack et al. 2001; Yazıcıoğlu 2014), Perca fluviatilis (Wziatek et al. 2004; Yazıcıoğlu et al. 2012), Sander lucioperca (Lozys 2003), Silurus glanis (Wysujack and Mehner 2005), Lutra lutra (Kemenes and Nechay 1990; Kloskowski et al. 2013), Mustela vison (Bartoszewicz and Zalewski 2003), and Vulpes vulpes (Jensen and Sequeira 1978).

Several studies have been conducted on the biology of white bream. Tadajewska (1993) analyzed the food composition of this species in Zegrzyński Dam Reservoir (Poland). Specziàr et al. (1997) studied the growth, diet and feeding strategy in the littoral zone of Lake Balaton (Hungary). Balik et al. (1999) investigated the growth and reproduction properties in Lake Kuş (Balikesir Province, Turkey). Gürsoy (2001) determined the size at maturity and fecundity in Lake Sapanca (Sakarya Province, Turkey). Hamalosmanoğlu (2003) and Okgerman et al. (2012) studied the growth and reproductive characteristics in Lake Sapanca. Tarkan et al. (2006) reported the length-weight relationship from Lake Sapanca. Şaşı and Berber (2012) examined the age and growth in Uluabat Lake (Bursa Province, Turkey). Yilmaz et al. (2012) researched the seasonal variations of the length-weight relationship and the relative condition in Lake Ladik (Samsun Province, Turkey). Jamali et al. (2015) investigated its age, size, and some biological aspects in Aras Dam Lake (Western Azerbaijan Province, Iran). The objectives of the present study were to: (1) determine the most reliable aging method for white bream by comparative analysis of two hard structures; (2) provide the information on age structure and growth features; and (3) assess the reproduction period of B. bjoerkna living in Lake Ladik, Samsun Province, Turkey.

\section{Materials and Methods}

Lake Ladik $\left(40^{\circ} 50^{\prime} \mathrm{N}\right.$ to $41^{\circ} 00^{\prime} \mathrm{N}, 35^{\circ} 40^{\prime} \mathrm{E}$ to $\left.36^{\circ} 05^{\prime} \mathrm{E}\right)$ is located within the borders of Samsun Province in the central Black Sea region of Turkey. This lake is $10 \mathrm{~km}$ far from Ladik district and it is a wetland with eutrophic character, has surface area of $10 \mathrm{~km}^{2}$ and maximum depth of $6 \mathrm{~m}$ (Y1lmaz et al. 2012). A total of 434 fish were collected monthly between November 2009 and October 2010 using gillnets and trammel nets. Gillnets had five panels (100 $\mathrm{m}$ long and $2 \mathrm{~m}$ deep) with varying mesh size $(20 \times 20,25 \times 25,30 \times 30,35 \times 35$ and $40 \times 40 \mathrm{~mm}$ ) and trammel nets had five panels (100 $\mathrm{m}$ long and $4 \mathrm{~m}$ deep) with varying mesh size $(45 \times 45,50 \times 50,55 \times 55,60 \times 60$ and $70 \times 70 \mathrm{~mm})$. Fork lengths were measured to the nearest $0.1 \mathrm{~cm}$ and total weights were weighed to the nearest $0.01 \mathrm{~g}$. The sex was determined by the visual examination of gonads. The gonad weight was recorded with $0.01 \mathrm{~g}$ precision. The differences between mean length and weight values of females and males were tested with Mann-Whitney $\mathrm{U}$ test $(\alpha=0.05)$ (Zar 1999). Length-frequency and weight-frequency distributions of sexes were compared by using Kolmogorov-Smirnov Z test ( $\alpha=0.05$ ) (Zar 1999).

Scales and vertebrae were removed from all individuals for aging. Scales were taken from the left anteriodorsal region of fish. Vertebrae $\left(4^{\text {th }}-10^{\text {th }}\right)$ were extracted. These calcified structures were prepared for age estimation by appropriate techniques. Scales were cleaned in a $3 \%$ solution of $\mathrm{NaOH}$ for 3-6 h, dried with blotting paper, and fixed between two glass slides. Dissected vertebrae were placed in boiling distilled water for 2-4 min, cleaned off the excess tissues, and stored as dry in labeled envelopes (Chugunova 1963). In order to determine the best aging structure, we compared ages estimated from scales and vertebrae for 122 specimens captured between January and March 2010. Each bony structure was aged twice at different times by three readers. Precision (reproducibility) of these age estimates were measured by calculating the percent agreement $(P A)$, average percent error $(A P E)$ and coefficient of variation $(C V)$ within reader and between readers, i.e. reproducibility within reader was based on the two (first and second) replicate counts of one reader, and reproducibility between readers was based on the second count by readers. $P A$ was the percent of full agreement between readings. $A P E$ for the $j$ th fish was computed by following equation (Beamish and Fournier 1981): 


$$
A P E=\frac{1}{R} \sum_{i=1}^{R} \frac{\left|x_{i j}-x_{j}\right|}{x_{j}} \times 100
$$

where $x_{i j}$ is the $i$ th age determination of the $j$ th fish, $x_{j}$ is the average age calculated for the $j$ th fish, and $R$ is the number of times each fish aged. $C V$ for the $j$ th fish was written as follows (Chang 1982):

$C V=\frac{\sqrt{\sum_{i=1}^{R} \frac{\left(x_{i j}-x_{j}\right)^{2}}{R-1}}}{x_{j}} \times 100$

The bony structure having the highest $P A$, and the lowest $A P E$ and $C V$ values is preferred as the most reliable hard part for age analysis.

The growth in length and weight was described with the von Bertalanffy growth equations (Sparre and Venema 1998):

$L_{t}=L_{\infty}\left[1-e^{-k(t-t)} 0^{\prime}\right]$

$W_{t}=W_{\infty}\left[1-e^{-k(t-t)} 0\right]^{b}$

where $L_{t}$ is the fork length at age $t, L_{\infty}$ is the asymptotic fork length, $k$ is the body growth coefficient, $t_{0}$ is the theoretical age at zero length, $W_{t}$ is the weight age $t, W_{\infty}$ is the asymptotic weight, and $b$ is the slope of length-weight relationship. The growth performance index was calculated by the equation of Munro and Pauly (1983):

$\Phi^{\prime}=\log k+2 \log L_{\infty}$

This index was used to compare the growth parameters obtained in the present study with those reported by others. The parameters $\left(L_{\infty}, k\right.$ and $\left.t_{0}\right)$ of the von Bertalanffy growth equations and $\Phi^{\prime}$ values were computed with FISAT II packaged software (Gayanilo et al. 2005) and the parameters $W_{\infty}$ and $b$ were obtained from the length-weight relationship. The relationship between fork length and weight was determined by the commonly used equation (Bagenal and Tesch 1978):

$W=a L^{b}$

where $W$ is the weight, $L$ is the fork length, $a$ is the intercept, and $b$ is the slope. The parameters $a$ and $b$ of the length-weight relationship were estimated by linear regression analysis on log-transformed data. Whether the growth of fish was isometric $(b=3)$ or allometric $(b>3$ or $b<3)$ was assessed by the student's t-test (Zar 1999). The Fulton's condition factor $(K)$ was calculated for each individual fish and evaluated according to sexes and months.
This index was expressed by the following equation (Ricker 1975):

$K=100 W L^{-3}$

where $W$ is the weight of the fish and $L$ is the fork length of the fish. The mean $K$ values were compared using the student t-test between sexes and within the same month (Zar 1999). To determine the reproduction season, we used the gonadosomatic index $(G S I)$. The values of GSI were computed via the formula (Holden and Raitt 1974):

\section{$G S I=100 G W / W-G W$}

where $G W$ is the gonad weight and $W$ is the fish weight. The water temperature was measured monthly during the sampling period and it was associated with the reproduction season.

\section{Results}

\section{Length and weight composition}

The fork lengths of 434 specimens (219 females and 215 males) varied between 11.5 and $24.3 \mathrm{~cm}$, with the average of $16.21 \pm 0.10 \mathrm{~cm}$ and their weights varied between 22.80 and $259.00 \mathrm{~g}$, with the average of $73.09 \pm 1.72 \mathrm{~g}$. There was no statistical difference between the average length and weight values of females and males (Table 1). The fork length-frequency $(Z=0.790, p>0.05)$ and weight-frequency $(Z=0.541, p>0.05)$ distributions were not different between sexes (Figure 1).

\section{Length-weight relationship}

The length-weight relationship of white bream was found as $W=0.0066 F L^{3.317}$ for both sexes $\left(n=434, r^{2}=0.968\right)$. The parameter $b$ of length-weight relationship was different from 3 (3.317 $\pm 0.029, p<0.001)$. This result indicated a positive allometric growth for $B$. bjoerkna. The length-weight relationship was plotted for all individuals (Figure 2).

\section{Reliable hard structure for aging}

Scale ages were more precise than vertebrae ages for each reader. Similarly, precision of scale ages among three readers was also better than precision of vertebra ages (Table 2). These findings demonstrated that scales are the best bony structure for age determination of the white bream in Lake Ladik.

\section{Age and growth}

The age of the fish samples were determined from scales because of the advantages such as easy collection, preparation and the more precise ageing results. However, the ages of 
34 fish could not be determined due to the absorptions in scales. The white bream population was represented by six age groups, ranging from 1 to 6 years. Age group III was dominant with $42 \%$ and followed by age group IV with $37 \%$ (Figure 3 ).

Table 1. Monthly mean fork length and weight values of females and males of white bream and differences between sexes tested by Mann-Whitney U test.

\begin{tabular}{|c|c|c|c|c|c|c|}
\hline Month & Sex & $n$ & $F L \pm S E$ & $p=0.05$ & $W \pm S E$ & $p=0.05$ \\
\hline \multirow{2}{*}{ Nov.09 } & $F$ & 19 & $15.02 \pm 0.44$ & \multirow{2}{*}{$<0.05$} & $55.5 \pm 6.1$ & \multirow{2}{*}{$>0.05$} \\
\hline & $M$ & 9 & $13.87 \pm 0.62$ & & $42.9 \pm 8.1$ & \\
\hline \multirow{2}{*}{ Dec.09 } & $F$ & 44 & $14.98 \pm 0.17$ & \multirow{2}{*}{$>0.05$} & $52.9 \pm 1.9$ & \multirow{2}{*}{$>0.05$} \\
\hline & $M$ & 39 & $15.02 \pm 0.18$ & & $52.8 \pm 2.0$ & \\
\hline \multirow{2}{*}{ Jan.10 } & $F$ & 8 & $17.02 \pm 0.69$ & \multirow{2}{*}{$>0.05$} & $87.8 \pm 11.0$ & \multirow{2}{*}{$>0.05$} \\
\hline & $M$ & 5 & $18.14 \pm 0.50$ & & $99.6 \pm 11.0$ & \\
\hline \multirow{2}{*}{ Feb.10 } & $F$ & 23 & $18.02 \pm 0.40$ & \multirow{2}{*}{$>0.05$} & $98.4 \pm 6.2$ & \multirow{2}{*}{$>0.05$} \\
\hline & $M$ & 22 & $18.72 \pm 0.36$ & & $112.3 \pm 6.8$ & \\
\hline \multirow{2}{*}{ Mar.10 } & $F$ & 36 & $15.56 \pm 0.43$ & \multirow{2}{*}{$>0.05$} & $64.9 \pm 7.6$ & \multirow{2}{*}{$>0.05$} \\
\hline & $M$ & 29 & $16.29 \pm 0.51$ & & $75.6 \pm 8.4$ & \\
\hline \multirow{2}{*}{ Apr.10 } & $F$ & 19 & $17.68 \pm 0.62$ & \multirow{2}{*}{$>0.05$} & $100.4 \pm 13.0$ & \multirow{2}{*}{$>0.05$} \\
\hline & $M$ & 17 & $17.34 \pm 0.58$ & & $89.8 \pm 10.0$ & \\
\hline \multirow{2}{*}{ May.10 } & $F$ & 15 & $18.15 \pm 0.36$ & \multirow{2}{*}{$<0.05$} & $107.2 \pm 8.9$ & \multirow{2}{*}{$<0.05$} \\
\hline & $M$ & 35 & $16.67 \pm 0.33$ & & $79.7 \pm 5.3$ & \\
\hline \multirow{2}{*}{ Jun.10 } & $F$ & 6 & $16.60 \pm 0.37$ & \multirow{2}{*}{$>0.05$} & $77.5 \pm 4.6$ & \multirow{2}{*}{$>0.05$} \\
\hline & $M$ & 9 & $17.63 \pm 0.47$ & & $91.1 \pm 7.2$ & \\
\hline \multirow{2}{*}{ Jul.10 } & $F$ & 17 & $15.45 \pm 0.28$ & \multirow{2}{*}{$>0.05$} & $57.5 \pm 3.7$ & \multirow{2}{*}{$>0.05$} \\
\hline & $M$ & 15 & $14.94 \pm 0.41$ & & $53.8 \pm 5.9$ & \\
\hline \multirow{2}{*}{ Aug.10 } & $F$ & 6 & $16.48 \pm 0.25$ & \multirow{2}{*}{$>0.05$} & $77.3 \pm 4.4$ & \multirow{2}{*}{$>0.05$} \\
\hline & $M$ & 9 & $16.24 \pm 0.16$ & & $78.3 \pm 2.6$ & \\
\hline \multirow{2}{*}{ Sep.10 } & $F$ & 18 & $16.44 \pm 0.49$ & \multirow{2}{*}{$>0.05$} & $73.1 \pm 7.1$ & \\
\hline & $M$ & 9 & $16.77 \pm 0.57$ & & $78.6 \pm 6.6$ & $>0.05$ \\
\hline & $F$ & 8 & $15.50 \pm 0.70$ & $>005$ & $61.0 \pm 9.4$ & \\
\hline Uct.10 & $M$ & 17 & $14.63 \pm 0.56$ & $>0.05$ & $50.1 \pm 5.9$ & $>0.05$ \\
\hline & $F$ & 219 & $16.18 \pm 0.15$ & & $72.6 \pm 2.5$ & \\
\hline I otal & $M$ & 215 & $16.24 \pm 0.16$ & $>0.05$ & $73.5 \pm 2.4$ & $>0.05$ \\
\hline
\end{tabular}

$n$ : Sample size, FL: Fork length, $W$ : Weight, $S E$ : Standard error, $p$ : Probability.
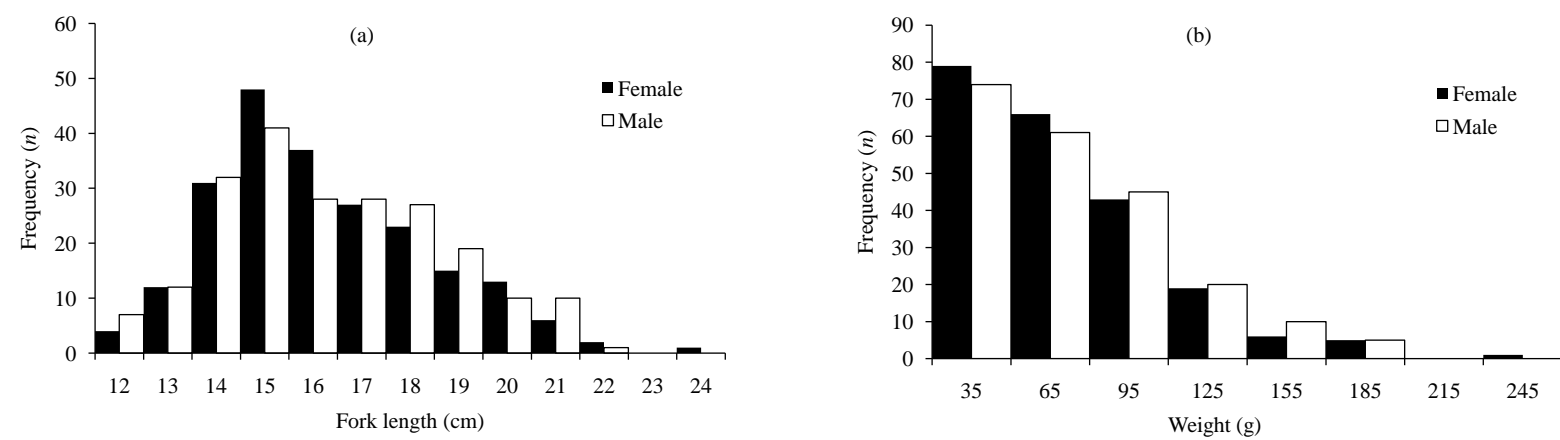

Figure 1. Length-frequency (a) and weight-frequency (b) distributions of female and male white breams.

Since there was no significant difference in the mean length and the weight value of female and male individuals at the same age group, the age-length and the age-weight relationships were calculated for all specimens. Age-length key for all specimens is given in Table 3.

The von Bertalanffy growth equation was found to be:
$L_{t}=32.85\left[1-e^{-0.11(t+2.64)}\right]$

in length and

$W_{t}=707.76\left[1-e^{-0.11(t+2.64)}\right]^{3.317}$

in weight. The growth performance index $(\Phi)$ value was computed as 2.074 for all samples. 
Table 2. Precision of age estimates obtained from readings of three readers.

\begin{tabular}{cccccc}
\hline Reader & Bony structure & $n$ & $P A$ & $A P E( \pm S E)$ & $C V( \pm S E)$ \\
\hline \multirow{2}{*}{ a } & Scale & 122 & 62.30 & $5.52(0.70)$ & $7.80(0.99)$ \\
& Vertebra & 122 & 54.92 & $6.27(0.66)$ & $8.87(0.94)$ \\
\hline \multirow{2}{*}{$\mathrm{b}$} & Scale & 122 & 60.66 & $5.37(0.64)$ & $7.60(0.90)$ \\
& Vertebra & 122 & 61.48 & $5.75(0.70)$ & $8.14(0.99)$ \\
\hline \multirow{2}{*}{$\mathrm{c}$} & Scale & 122 & 62.30 & $5.17(0.62)$ & $7.31(0.88)$ \\
& Vertebra & 122 & 40.16 & $9.76(0.84)$ & $13.80(1.19)$ \\
\hline \multirow{2}{*}{ a, b, c } & Scale & 122 & 13.93 & $9.27(0.06)$ & $12.42(0.45)$ \\
& Vertebra & 122 & 13.11 & $10.45(0.53)$ & $13.56(0.65)$ \\
\hline
\end{tabular}

$n$ : Sample size, $P A$ : Percent agreement, $A P E$ : Average percent error, $C V$ : Coefficient of variation, $S E$ : Standard error.

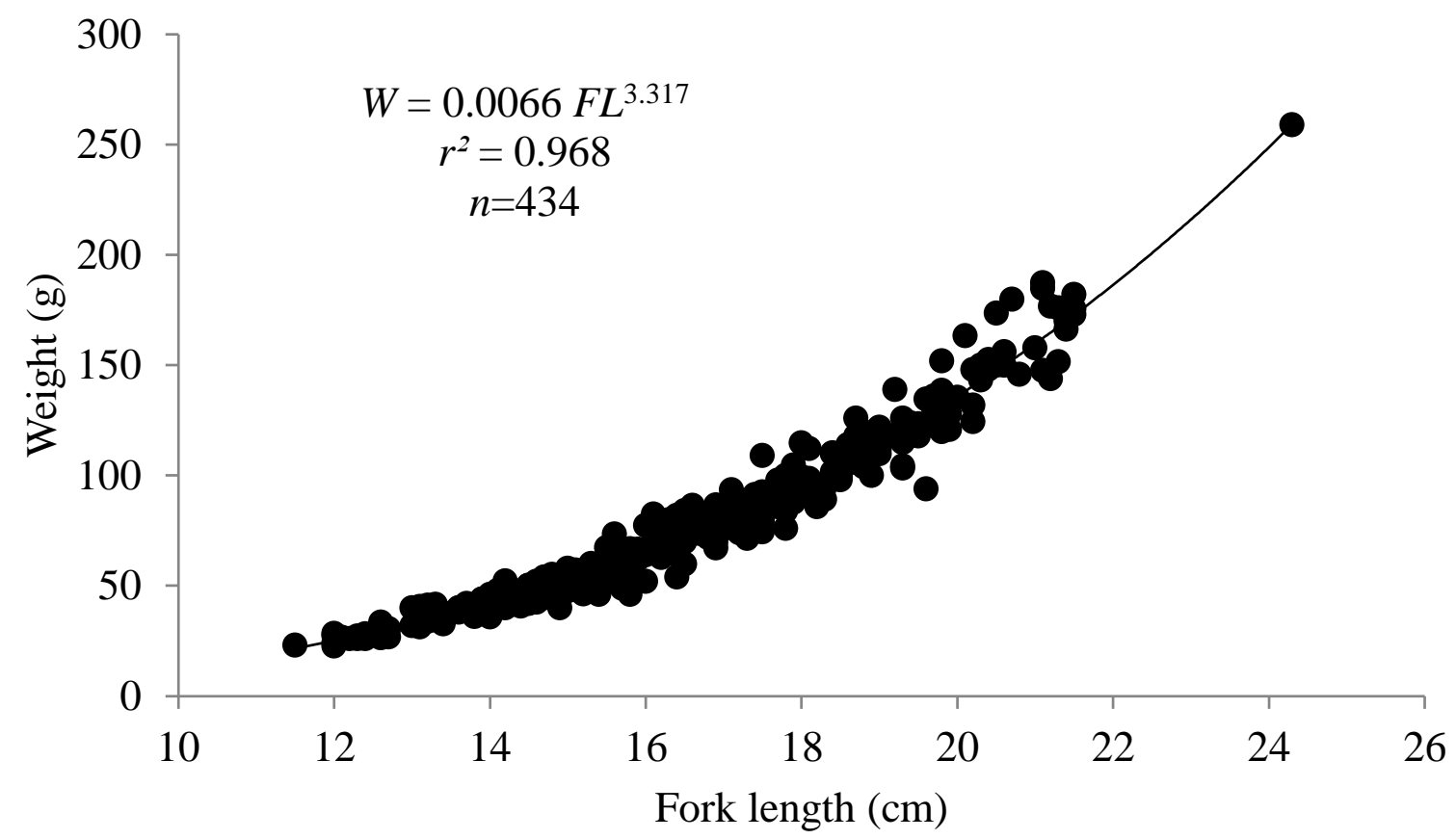

Figure 2. Relationship between length and weight for all samples of white bream.

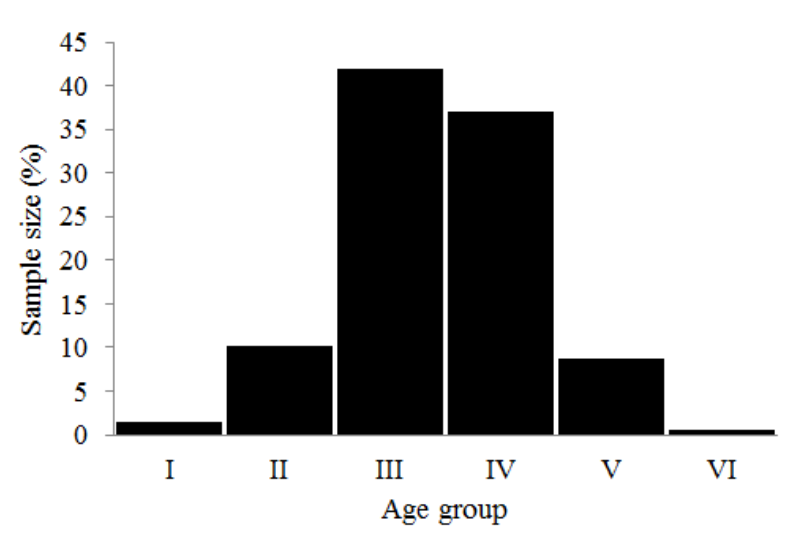

Figure 3. Age composition of white bream.

\section{Condition factor}

The values of $K$ varied from 1.168 to 2.036 with the mean of 1.589 for females and from 1.209 to 2.017 with the mean of 1.593 for males. There was no significant difference in the mean $K$ between sexes $(p>0.05)$.
The average $K$ of white bream population was calculated as 1.591. No significant difference was observed in the mean $K$ of females and males within the same month (t-test, $p>0.05$ ). Monthly mean $K$ ranged from 1.493 to 1.781 for combined sexes. The mean $K$ was the highest in August and the lowest in October (Figure 4).

\section{Reproductive period}

The values of GSI ranged from 0.583 to 16.134 in females and from 0.193 to 6.300 in males. The highest average value of GSI was observed in May for females (6.821) and April for males (3.027). The lowest average values of GSI were found in July for both sexes (Figure 5). It can be said that the reproduction season of the white bream population in Lake Ladik is between May and June. The water temperature in these months was measured as $19.9^{\circ} \mathrm{C}$ and $23.7^{\circ} \mathrm{C}$, respectively. 
Table 3. Age-length key of white bream based on scale readings.

\begin{tabular}{|c|c|c|c|c|c|c|c|}
\hline \multirow{2}{*}{$\begin{array}{l}\text { Length } \\
\text { intervals } \\
(\mathrm{cm})\end{array}$} & \multicolumn{6}{|c|}{ Age group (year) } & \multirow{2}{*}{ Total } \\
\hline & I & II & III & IV & $\mathrm{V}$ & VI & \\
\hline $11.5-12.4$ & 4 & 7 & & & & & 11 \\
\hline $12.5-13.4$ & 2 & 11 & 11 & & & & 24 \\
\hline $13.5-14.4$ & & 7 & 51 & 4 & & & 62 \\
\hline $14.5-15.4$ & & 9 & 64 & 13 & & & 86 \\
\hline $15.5-16.4$ & & 5 & 26 & 30 & & & 61 \\
\hline $16.5-17.4$ & & 1 & 11 & 36 & & & 48 \\
\hline $17.5-18.4$ & & 1 & 5 & 34 & 6 & & 46 \\
\hline $18.5-19.4$ & & & & 19 & 11 & & 30 \\
\hline $19.5-20.4$ & & & & 12 & 6 & 1 & 19 \\
\hline $20.5-21.4$ & & & & & 10 & & 10 \\
\hline $21.5-22.4$ & & & & & 2 & & 2 \\
\hline \multicolumn{8}{|l|}{$22.5-23.4$} \\
\hline $23.5-24.4$ & & & & & & 1 & 1 \\
\hline$n$ & 6 & 41 & 168 & 148 & 35 & 2 & 400 \\
\hline$\% n$ & 1.50 & 10.25 & 42.00 & 37.00 & 8.75 & 0.50 & 100.00 \\
\hline $\begin{array}{l}\text { Mean } F L \pm S E \\
(\text { Min-Max })\end{array}$ & $\begin{array}{l}12.23 \pm 0.19 \\
(11.5-12.7)\end{array}$ & $\begin{array}{l}14.02 \pm 0.22 \\
(12.0-17.7)\end{array}$ & $\begin{array}{l}14.86 \pm 0.08 \\
(12.6-17.9)\end{array}$ & $\begin{array}{l}17.19 \pm 0.12 \\
(14.1-20.3)\end{array}$ & $\begin{array}{c}19.7 \pm 0.22 \\
(17.5-21.5)\end{array}$ & $\begin{array}{c}22.3 \pm 2.00 \\
(20.3-24.3)\end{array}$ & $\begin{array}{l}16.21 \pm 0.10 \\
(11.5-24.3)\end{array}$ \\
\hline $\begin{array}{l}\text { Mean } W \pm S E \\
(\text { Min-Max })\end{array}$ & $\begin{array}{c}26.13 \pm 1.18 \\
(22.8-30.62)\end{array}$ & $\begin{array}{l}41.85 \pm 2.14 \\
(24.1-86.0)\end{array}$ & $\begin{array}{c}51.31 \pm 1.01 \\
(32.0-99.22)\end{array}$ & $\begin{array}{c}84.9 \pm 1.88 \\
(40.88-152.0)\end{array}$ & $\begin{array}{c}135.87 \pm 5.25 \\
(87.63-187.38)\end{array}$ & $\begin{array}{c}204.5 \pm 54.50 \\
(150.0-259.0)\end{array}$ & $\begin{array}{c}73.09 \pm 1.72 \\
(22.8-259.0)\end{array}$ \\
\hline
\end{tabular}

$n$ : Sample size, FL: Fork length, W: Weight, Min: Minimum, Max: Maximum, SE: Standard error.

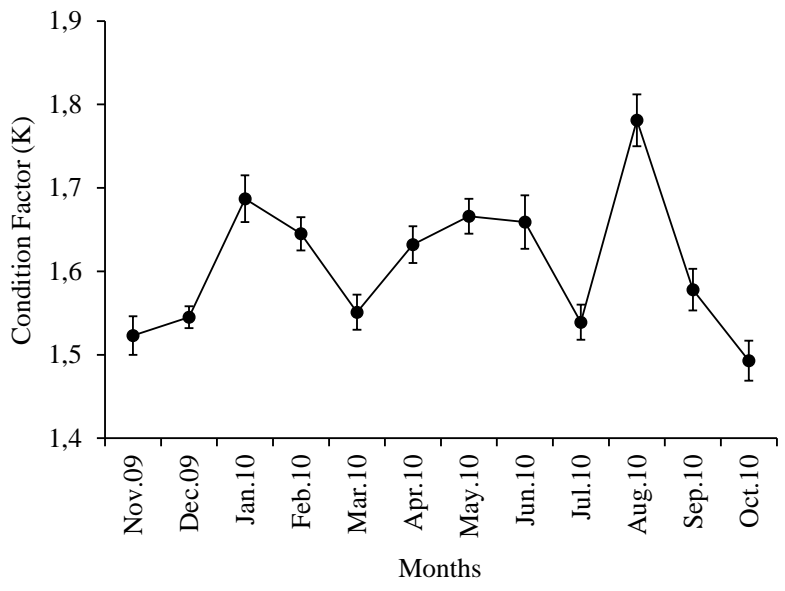

Figure 4. Monthly variations in the mean value (solid circle) of condition factor for all individuals of white bream. Vertical bar represents the standard error of the mean.

\section{Discussion}

The maximum length and weight values measured in this study were higher than those of Balık et al. (1999), Okgerman et al. (2012), and Şaş1 and Berber (2012). In contrast, our results were lower than those of Hamalosmanoğlu (2003) and Jamali et al. (2015). Differences can be attributed to fishing methods, population density, and ecological characteristics of studied areas (Y1lmaz et al. 2012).

It was determined that the growth of B. bjoerkna was positive allometric for both sexes. Our finding

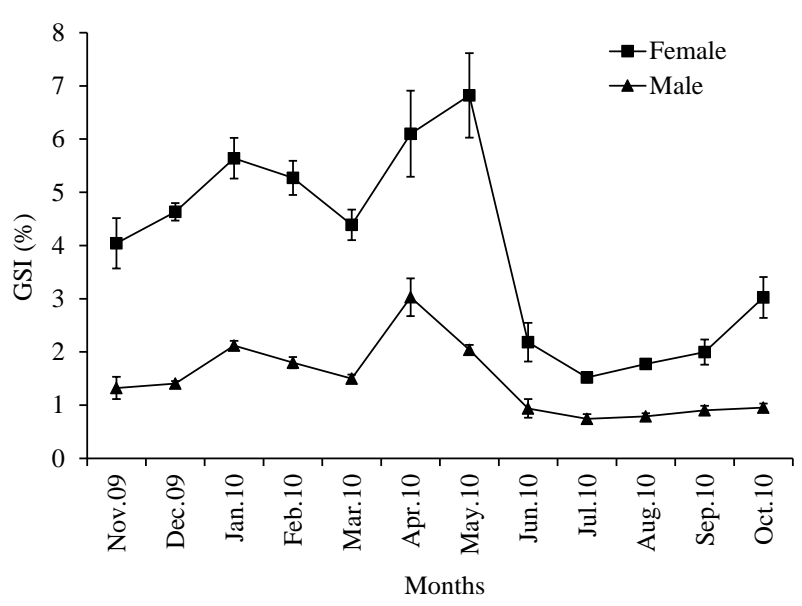

Figure 5. Monthly mean gonadosomatic index (GSI) values for female and male white breams. Vertical bar represents the standard error of the mean.

was in agreement with the result of Hanel (1991) (see Okgerman et al. 2012), Specziár et al. (1997), Balık et al. (1999), Tarkan et al. (2006), Okgerman et al. (2012), and Jamali et al. (2015). In contrast, Şaş1 and Berber (2012) reported that the growth of the white bream population in Uluabat Lake was negative allometric with $b$ value of 2.58. The parameter $b$ of length-weight relation in fish can vary between 2 and 4. Moreover, length-weight relationships are affected by a number of factors including food availability, feeding rate, gonad 
development, and spawning period as well as season, sex and habitat (Bagenal and Tesch 1978).

We concluded that scales of the white bream from Lake Ladik provide better age estimates than vertebrae. In the majority of previous studies, the age of $B$. bjoerkna has been determined by using the scale method (Balık et al. 1999; Hamalosmanoğlu 2003; Şaş1 and Berber 2012; Okgerman et al. 2012). Our finding supports earlier investigations in terms of age estimation. In fact, scales have been reported to ensure more precise age results when compared to other bony structures in some cyprinid fish species such as Capoeta capoeta (Polat and Beamish 1992), Chondrostoma regium (Polat and Gümüş 1995), Squalius cephalus (Y1lmaz et al. 2007), Alburnus chalcoides (Y1lmaz and Suiçmez 2010), Abramis brama (Erbaşaran 2012). However, the absorptions of calcified tissue in cases of severe stress may prevent the use of scales for accurate age determination (Quist et al. 2012). In this study, 34 scales could not be read due to the absorptions.

Ages of the white bream specimens in Lake Ladik varied between 1-6 years. The absence of age group 0 can be attributed the mesh size of fishing nets. The maximum age of B. bjoerkna was reported as 4 years in Lake Kuş (Balık et al. 1999), 8 years in
Lake Sapanca (Hamalosmanoğlu 2003), 9 years in Lake Sapanca (Okgerman et al. 2012), 7 years in Lake Uluabat (Şaş1 and Berber 2012), and 5 years in Aras Dam Lake (Jamali et al. 2015). These differences may be due to several reasons such as variations in sampling period and method, potential aging errors, and overfishing.

Regarding the calculation of the von Bertalanffy growth equation parameters, a low estimate of $k$ and a high $L_{\infty}$ and $W_{\infty}$ indicated that white bream is slow-growing and long-lived fish. Kottelat and Freyhof (2007) stated that white bream could live more than 10 years. The $L_{\infty}$ and $W_{\infty}$ values obtained in our work were greater than those of previous studies (Table 4 ). In contrast, the $k$ value calculated in this study was similar to that obtained by Ilyina (1960) (see Okgerman et al. 2012), Specziar et al. (1997) and Şaşı and Berber (2012), and lower than scores of Hanel (1991) (see Okgerman et al. 2012), Balık et al. (1999) and Okgerman et al. (2012). Several factors such as different size distributions and different study areas may be causes of differences among all of the estimated parameters (Ma et al. 2010). Nevertheless, the growth performance index value found in present study was similar to those of the earlier studies (Table 4).

Table 4. The von Bertalanffy growth equation parameters and growth performance index values in different populations of white bream.

\begin{tabular}{llcccccc}
\hline Reference & Locality & Sex & $L_{\infty}$ & $W_{\infty}$ & $k$ & $t_{0}$ & $\Phi^{\prime}$ \\
\hline Ilyina 1960* & Gorkovsky Lake & All & $30.98(\mathrm{FL})$ & - & 0.110 & - & 2.02 \\
Hanel 1991* & Berounka River & All & $23.40(\mathrm{SL})$ & - & 0.270 & -0.270 & 2.17 \\
Specziár et al. 1997 & Lake Balaton & All & $35.90(\mathrm{SL})$ & - & 0.098 & -0.639 & 2.10 \\
Balık et al, 1999 & Lake Kuş & All & $18.92(\mathrm{FL})$ & $155.19^{* *}$ & 0.374 & -0.248 & 2.13 \\
& & Female & $31.92(\mathrm{TL})$ & $496.23^{* *}$ & 0.122 & -1.087 & 2.10 \\
Okgerman et al. 2012 & Lake Sapanca & Male & $22.17(\mathrm{TL})$ & $133.03^{* *}$ & 0.215 & -0.986 & 2.02 \\
& & All & $28.00(\mathrm{FL})$ & 625.15 & 0.109 & -3.853 & 1.93 \\
Saş̧ and Berber 2012 & Lake Uluabat & All & $32.85(\mathrm{FL})$ & 707.76 & 0.110 & -2.640 & 2.07 \\
\hline
\end{tabular}

*Taken from Okgerman et al. 2012,**Calculated from length-weight relationship.

Balık et al. (1999) and Şaş1 and Berber (2012) reported higher minimum and maximum values for $K$ (1.14-2.65 and 1.27-2.87, respectively), compared to this study (1.17-2.04). The mean $K$ of the investigated species did not show significant difference between females and males, in contrast with the finding of Okgerman et al. (2012). The mean $K$ value (1.59) obtained for entire specimens in present work was greater than the result (1.50) of Hamalosmanoğlu (2003). The mean $K$ values of B. bjoerkna in Lake Ladik were the highest in August (1.78) and the lowest in October (1.49) for all samples. However, the maximum and minimum mean $K$ values for white bream population in Lake Sapanca were observed in May (1.72) and December (1.39), respectively (Hamalosmanoğlu 2003). Additionally, Okgerman et al. (2012) reported that mean $K$ coefficient was at the maximal level in April (1.33) for females, while it was highest in March (1.22) for males. Changes in fish condition primarily reflect state of sexual maturity and nutrition level (Wootton 1990; Williams 2000). Also, the condition factor is affected by variables such as habitat, year, season, age group, and sex (Erkoyuncu 1995). 
In this study the maximum value of mean GSI was observed in May for females, while it was obtained in April for males. Similarly, Okgerman et al. (2012) reported that the mean GSI values of female and male white breams in Lake Sapanca peaked in April for former and in March for latter. These differences between sexes can be attributed to the high number of immature male individuals in above-mentioned months. Hamalosmanoğlu (2003) also reported that the average GSI in females reached the highest level in May. A relatively short spawning period for white bream in Lake Ladik was determined between May and June at temperature of $19.9^{\circ} \mathrm{C}-23.7^{\circ} \mathrm{C}$. Our results are quite similar to the findings of previous studies in different localities (Table 5).

Table 5. The reproduction seasons of white bream populations from different localities.

\begin{tabular}{lllc}
\hline Reference & Locality & Spawning Period & Temperature $\left({ }^{\circ} \mathrm{C}\right)$ \\
\hline Balık et al. 1999 & Lake Kuş & From mid-April to early June & $21-24$ \\
Gürsoy 2001 & Lake Sapanca & May & $18-20$ \\
Hamalosmanoğlu 2003 & Lake Sapanca & From mid-May to late June & $15-23$ \\
Okgerman et al. 2012 & Lake Sapanca & From mid-April to early July & $13.7-28.5$ \\
This study & Lake Ladik & May-June & $19.9-23.7$ \\
\hline
\end{tabular}

The start and end dates of spawning season can vary due to the ecological and climatic conditions. Reproduction periods may also change depending on some factors such as fish species, habitat type (lake or river), altitude, water temperature, and food quality (Nikolsky 1963).

Consequently, this study provides basic information on age, growth, and spawning season of white bream living in Lake Ladik, characterized as eutrophic. The results obtained from this work may be useful to maintain more effective fishery management of the studied species.

\section{Acknowledgements}

We would like to thank to the local fishermen for their help during sampling.

\section{References}

Abecasis D, Bentes L, Coelho R, Correia C, Lino PG, Monteiro P, Gonçalves JMS, Ribeiro J, Erzini K. 2008. Ageing seabreams: a comparative study between scales and otoliths. Fish Res. 89(1):37-48. doi: 10.1016/j.fishres.2007.08.013

Bagenal TB, Tesch FW. 1978. Age and growth. In: Bagenal TB, editor. Methods for assessment of fish production in freshwaters. Oxford: Blackwell Science Publication. p. 101-136.

Balık S, Ustaoğlu MR, Sarı HM. 1999. Investigations on growth and reproduction characteristics of white bream (Blicca bjoerkna L., 1758) population in Lake Kuş (Bandırma). Istanbul Uni $J$ Aquat Prod. Special Issue:223-231. [in Turkish]

Bartoszewicz M, Zalewski A. 2003. American mink, Mustela vison diet and predation on waterfowl in the Słońsk Reserve, Western Poland. Folia Zool. 52(3):225-230.
Beamish RJ, Fournier DA. 1981. A method for comparing the precision of a set of age determinations. Can J Fish Aquat Sci. 38(8):982-983. doi: 10.1139/F81-132

Chang WYB. 1982. A statistical method for evaluating the reproducibility of age determination. Can J Fish Aquat Sci. 39(8):1208-1210. doi: 10.1139/f82-158

Chugunova NI. 1963. Age and Growth Studies in Fish. Washington: National Science Foundation. 132 p.

DeVries DR, Frie RV. 1996. Determination of age and growth. In: Murphy BR, Willis DW, editors. Fisheries techniques. 2nd edition. Maryland: American Fishery Society. p. 483-512.

Erbaşaran E. 2012. Age determination and investigation of growth features of common bream, Abramis brama (L., 1758) in Lake Ladik (Samsun, Turkey) [Master's Thesis]. Ondokuz Mayıs University. 67 p. [in Turkish]

Erkoyuncu İ. 1995. Balıkçılık Biyolojisi ve Populasyon Dinamiği. Samsun: Ondokuz Mayıs Üniversitesi Basımevi. 265 p. [in Turkish]

Gayanilo PC, Sparre P, Pauly D. 2005. FAO-ICLARM stock assessment tools II (FISAT II). Revised version. User's guide. Rome: FAO. Computerized Information Series No.:8

Geldiay R, Balık S. 2007. Türkiye Tatlısu Balıkları. İzmir: Ege Üniversitesi Basımevi. 644 p. [in Turkish]

Gürsoy Ç. 2001. Size at maturity and fecundity of white breams (Blicca bjoerkna L., 1758) baltic vimba (Vimba vimba L., 1758) fish populations in Sapanca Lake [Master's Thesis]. İstanbul University. 20 p. [in Turkish]

Hamalosmanoğlu, M. 2003. Growth and reproduction features of vimba (Vimba vimba L., 1758) and white bream (Blicca bjoerkna L., 1758) living in Sapanca Lake [PhD Thesis]. Gazi University. 79 p. [in Turkish]

Holden MC, Raitt DFS. 1974. Manual of fisheries science part 2- methods of resource investigation and their application. Rome: FAO. Technical Paper No.:115. 
Jamali H, Eagderi S, Esmaeilzadegan E, Patimar R. 2015. Age, growth and some biological characteristics of Silver bream (Blicca bjoerkna L., 1758) (Cyprinidae) from Aras Dam Lake in Northwest of Iran. Int J Biol. 3(1):35-41.

Jensen B, Sequeira DM. 1978. The diet of the Red Fox (Vulpes vulpes L.) in Denmark. Danish Review of Game Biology. 10(8):1-16.

Kemenes I, Nechay G. 1990. The food of otters Lutra lutra in different habitats in Hungary. Acta Theriologica. 35(1-2):17-24.

Khan S, Khan MA, Miyan K. 2011. Comparison of age estimates from otoliths, vertebrae, and pectoral spines in African sharptooth catfish, Clarias gariepinus (Burchell). Estonian J Ecol. 60(3):183-193. doi: 10.3176/eco.2011.3.02

Kloskowski J, Rechulicz J, Jarzynowa B. 2013. Resource availability and use by Eurasian otters Lutra lutra in a heavily modified river-canal system. Wildlife Biol. 19(4):439-451. doi: 10.2981/12-104

Kottelat M, Freyhof J. 2007. Handbook of European Freshwater Fishes. Cornol (Switzerland) and Berlin (Germany): Published by the authors $646 \mathrm{p}$.

Ložys L. 2003. Seasonal migrations of pikeperch (Sander lucioperca L.) from the Curonian Lagoon to the Baltic Sea and advantages of the phenomenon. Acta Zool Lit. 13(2):188-194. doi: 10.1080/13921657.2003.10512562

Ma BS, Xie CX, Hue B, Yang XF, Huang HP. 2010. Age and growth of a long-lived fish Schizothorax o'connori in the Yarlung Tsangpo River, Tibet. Zool Stud. 49(6):749-759.

Munro JL, Pauly D. 1983. A simple method for comparing growth of fishes and invertebrates. ICLARM Fishbyte. 1(1):5-6.

Nikolsky GV. 1963. The Ecology of Fishes. London: Academic Press 352 p.

Okgerman HC, Elp M, Atasagun S. 2012. The growth and reproduction of white bream (Blicca bjoerkna L. 1758) in an oligo-mesotrophic lake in northwest Anatolia (Sapanca, Turkey). Turk J Zool. 36(1):125-134. doi: 10.3906/biy-1012-157

Polat N. 2000. Importance of age determination in fish. Paper presented at: IV. Su Ürünleri Sempozyumu; Erzurum, Turkey. [in Turkish]

Polat N, Beamish RJ. 1992. Annulus formation on anatomical structures of Siraz (Capoeta capoeta) in Altınkaya Dam Lake. Ondokuz Mayıs Uni J Sci. 4(1):70-88.

Polat N, Gümüş A. 1995. Age determination and evaluation of precision using five bony structures of the Brond-Snout (Chondrostoma regium Heckel, 1843). Turk J Zool. 19:331-335.

Pontual H (de), Panfili J, Wright PJ, Troadec H. 2002. Introduction. In: Panfili J, Pontual H (de), Treodac H, Wright PJ, editors. Manual of fish sclerochronology. Brest (France): Ifremer-IRD coedition. p. 18-23.

Quist MC, Pegg MA, DeVries DR. 2012. Age and growth. In: Zale A, Parrish D, Sutton T, editors. Fisheries techniques. 3rd edition. Maryland: American Fishery Society. p. 677-731.
Ricker WE. 1975. Computation and interpretation of biological statistics of fish populations. Bull Fish Res Board Can. 191:1-382.

Şaş1 H, Berber S. 2012. Age, growth and some biological characteristics of white bream (Blicca bjoerkna L., 1758) in Uluabat Lake, in northwestern of Anatolia. Asian J Anim Vet Adv. 7(3):262-267. doi: 10.3923/ajava.2012.262.267

Sparre P, Venema SC. 1998. Introduction to tropical fish stock assessment part 1: manual. Rome: FAO. Fisheries Technical Paper No.:306/1.

Specziár A, Tölg L, Bíró P. 1997. Feeding strategy and growth of cyprinids in the littoral zone of Lake Balaton. J Fish Biol. 51(6):1109-1124. doi: 10.1111/j.1095-8649.1997.tb01130.x

Stolarski JT, Sutton TM. 2013. Precision analysis of three aging structures for amphidromous Dolly Varden from Alaskan Arctic rivers.N Am J Fish Manage. 33(4):732-740. doi: 10.1080/02755947.2013.806379

Tadajewska M. 1993. Food of bream, Abramis brama (L.) and white bream, Blicca bjoerkna (L.), in Zegrzyński Reservoir. Acta Ichthyol. Piscat. 23(2):77-101.

Tarkan AS, Gaygusuz Ö, Acıpınar H, Gürsoy Ç, Özuluğ M. 2006. Length-weight relationships of fishes from the Marmara Region (NW-Turkey). J Appl Ichthyol. 22(4):271-273. doi: 10.1111/j.1439-0426.2006.00711.x

Wielgosz S, Tadajewska M. 1988. Factors determining diet composition and food availability for bream, Abramis brama (L.), and white Bream, Blicca bjoerkna (L.), in Wloclawek Dam Reservoir. Acta Ichthyol Piscat. 18(1):79-100.

Williams JE. 2000. The coefficient of the condition in fish. In: Schneider JC, editor. Manual of fisheries survey methods II: with periodic updates. Ann Arbor: Michigan Department of Fisheries Resources. p. 1-2.

Wootton RJ. 1990. Ecology of Teleost Fishes. London: Chapman \& Hall. 404 p.

Wysujack K, Mehner T. 2005. Can feeding of European catfish prevent cyprinids from reaching a size refuge.Ecol Freshw Fish. 14(1):87-95. doi: 10.1111/j.1600-0633.2004.00081.x

Wysujack K, Laude U, Anwand K, Mehner T. 2001. Stocking, population development and food composition of pike Esox lucius in the biomanipulated Feldberger Haussee (Germany)-Implications for fisheries management. Limnologica. 31(1):45-51. doi: 10.1016/S0075-9511(01)80047-5

Wziątek B, Pocyzcyzński P, Kozłowski, J, Wojnar K. 2004. The feeding of sexually mature European perch (Perca fluviatilis L.) in the Lake Kortowskie in the Autumn-Winter period. Arch Pol Fish. 12(2):197-201.

Yazıcıoğlu O, Yılmaz S, Erbaşaran M, Polat N, Yazıcı R. 2012. Ladik Gölü (Samsun)'nde yaşayan tatlısu levreği (Perca fluviatilis L., 1758)'nin boy grupları ve mevsimlere gore beslenme özellikleri. Paper presented at: FABA2012 Sempozyumu; Eskişehir, Turkey. [in Turkish]

Yazıcıoğlu O. 2014. Biological features of pike (Esox lucius L., 1758) inhabiting Lake Ladik 
(Samsun) [PhD Thesis]. Ondokuz Mayıs University. 133 p. [in Turkish]

Yılmaz S, Suiçmez M. 2010. Age determination and growth of Alburnus chalcoides (Güldenstädt, 1772) population inhabiting Almus Dam Lake (Tokat). Black Sea J Sci. 1(2):7-20. [in Turkish]

Yılmaz S, Yazıcıoğlu O, Erbaşaran M, Esen S, Zengin M, Polat N. 2012. Length-weight relationship and relative condition factor of white bream, Blicca bjoerkna
(L., 1758), from Lake Ladik, Turkey. J Black Sea/Med Envir. 18(3):380-387.

Yilmaz S, Yilmaz M, Polat N. 2007. Age determination from six bony structures of chub (Leuciscus cephalus L., 1758) inhabiting Divanbasi Pond (Kavak, Samsun). Istanbul Uni J Fish Aqua Sci. 23:67-80. [in Turkish]

Zar JH. 1999. Biostatistical Analysis. New Jersey: Prentice-Hall 663 p. 